University of Nebraska - Lincoln

DigitalCommons@University of Nebraska - Lincoln

Publications from USDA-ARS / UNL Faculty

U.S. Department of Agriculture: Agricultural

Research Service, Lincoln, Nebraska

2017

\title{
Assessing soil structural quality under Brazilian sugarcane expansion areas using Visual Evaluation of Soil Structure (VESS)
}

\author{
Maurício R. Cherubin \\ University of São Paulo, cherubin@usp.br \\ André L.C. Franco \\ Colorado State University, andre.franco@colostate.edu \\ Rachel M.L. Guimarães \\ Federal University of Technology - Paraná \\ Cássio A. Tormena \\ State University of Maringá, cassiotormena@gmail.com \\ Carlos E. P. Cerri \\ University of São Paulo, cepcerri@usp.br \\ See next page for additional authors
}

Follow this and additional works at: https://digitalcommons.unl.edu/usdaarsfacpub

Cherubin, Maurício R.; Franco, André L.C.; Guimarães, Rachel M.L.; Tormena, Cássio A.; Cerri, Carlos E. P.; Karlen, Douglas; and Cerri, Carlos C., "Assessing soil structural quality under Brazilian sugarcane expansion areas using Visual Evaluation of Soil Structure (VESS)" (2017). Publications from USDA-ARS / UNL Faculty. 1655.

https://digitalcommons.unl.edu/usdaarsfacpub/1655

This Article is brought to you for free and open access by the U.S. Department of Agriculture: Agricultural Research Service, Lincoln, Nebraska at DigitalCommons@University of Nebraska - Lincoln. It has been accepted for inclusion in Publications from USDA-ARS / UNL Faculty by an authorized administrator of DigitalCommons@University of Nebraska - Lincoln. 


\section{Authors}

Maurício R. Cherubin, André L.C. Franco, Rachel M.L. Guimarães, Cássio A. Tormena, Carlos E. P. Cerri, Douglas Karlen, and Carlos C. Cerri 


\title{
Assessing soil structural quality under Brazilian sugarcane expansion areas using Visual Evaluation of Soil Structure (VESS)
}

\author{
Maurício R. Cherubin ${ }^{\mathrm{a}, \mathrm{b}, *}$, André L.C. Franco ${ }^{c}$, Rachel M.L. Guimarães ${ }^{\mathrm{d}}$, \\ Cássio A. Tormena ${ }^{\mathrm{e}}$, Carlos E.P. Cerri ${ }^{\mathrm{a}}$, Douglas L. Karlen ${ }^{\mathrm{f}}$, Carlos C. Cerri ${ }^{\mathrm{b}}$ \\ a University of São Paulo, “Luiz de Queiroz" College of Agriculture, Department of Soil Science, Piracicaba, SP 13418-900, Brazil \\ ${ }^{\mathrm{b}}$ University of São Paulo, Center for Nuclear Energy in Agriculture, Piracicaba, SP 13416-000, Brazil \\ ' Colorado State University, Department of Biology, Fort Collins, CO 80523, USA \\ d Federal University of Technology - Paraná, Department of Agronomy, Pato Branco, PR 85503-390, Brazil \\ e State University of Maringá, Department of Agronomy, Maringá, PR 87020-900, Brazil \\ ${ }^{\mathrm{f}}$ USDA-ARS, National Laboratory for Agriculture and the Environment (NLAE), Ames, IA 50011, USA
}

\section{A R T I C L E I N F O}

\section{Article history:}

Received 5 January 2016

Received in revised form 3 May 2016

Accepted 4 May 2016

Available online 7 July 2016

\section{Keywords:}

Land use change

Visual method

Soil physical properties

\section{A B S T R A C T}

Increasing global demand for biofuel has accelerated land-use change (LUC) in Brazil, primarily through the planting of sugarcane (Saccharum officinarum) to replace degraded pastures. The intensive mechanization associated with this LUC has increased concerns regarding structural quality of Brazilian tropical soils. Through decades of research focusing on identifying sensitive indicators of soil degradation due to land use and management, the Visual Evaluation of Soil Structure (VESS) method has emerged as a simple, fast, reliable and accurate semi-quantitative approach for assessing soil structure changes. VESS integrates soil properties related to size, strength and porosity of aggregates, and root characteristics into a single score ( $\mathrm{Sq}$ - structural quality) that ranges from 1 (good structural quality) to 5 (poor structural quality). Although the VESS method was developed for temperate soils, it has been used successfully as an indicator of soil and crop management practice effects on structural quality of tropical and subtropical soils. Our objectives were to evaluate soil structural quality changes associated with a LUC sequence (i.e., native vegetation to pasture to sugarcane) at three sites under Oxisols, Alfisols and Ultisols across centralsouthern Brazil using the VESS; and to correlate VESS scores with quantitative measurements of soil physical properties. Average VESS scores were 2.0, 2.7, and 3.1 for native vegetation, pasture, and sugarcane, respectively. Overall the VESS method was able to detect soil structural quality changes under LUC for sugarcane cultivation, indicating a decrease in soil quality from native vegetation through pasture to sugarcane. The VESS scores were significantly correlated with quantitative soil physical property measurements, suggesting VESS is a reliable indicator of soil structural quality in tropical soils. A VESS score $\mathrm{Sq}=3.0$ seems to be suitable as a guide for management decisions. We conclude that VESS scores provide an efficient method to identify impacts of sugarcane expansion on soil structural quality, and recommend that VESS assessment be incorporated into monitoring protocols for evaluating not only sugarcane expansion areas, but also overall soil quality/health in Brazil.

(c) 2016 Elsevier B.V. All rights reserved.

\section{Introduction}

The large-scale cultivation of biofuel crops for bioenergy has caused widespread transformations worldwide in land, either directly or through the replacement of other managed lands with food crops (Foley et al., 2005). Brazil, the world's largest producer

\footnotetext{
* Corresponding author at: University of São Paulo, Center for Nuclear Energy in Agriculture, Piracicaba, SP 13416-000, Brazil.

E-mail address: cherubin@usp.br (M.R. Cherubin).
}

of sugarcane ethanol [29.2 billion of liters per year (Companhia Nacional de Abastecimento, 2016)], is one of main sites where these land-use changes are occurring (Lapola et al., 2014). Throughout the last decade (2005-2015), the sugarcane area has increased from 5.8 to 9.0 Mha, with most of area being concentrated within the central-southern region (Companhia Nacional de Abastecimento, 2016). Nevertheless, in order to meet the projected domestic Brazilian supplies for ethanol by 2021, an additional 6.4 Mha of sugarcane will be required (Goldemberg et al., 2014). Historically, the expansion of agriculture in centralsouthern Brazil has occurred through removal of native vegetation 
and introduction of pasture. Unfortunately, due to poor management practices (Lapola et al., 2014) this land use conversion has resulted in vast areas of low-productivity pasture (Strassburg et al., 2014) and poor soil quality (Cherubin et al., 2016a). Conversion of extensive, low quality pasturelands to sugarcane has therefore become the most opportune and widespread land-use change to meet projected ethanol demands, and thus avoid direct competition for land with food crops and natural ecosystems (Goldemberg et al., 2014; Strassburg et al., 2014).

Conversion of pastureland to sugarcane production requires intensive mechanization through large and heavy agricultural machines that impose unavoidable modifications to soil structure and physical properties (Cherubin et al., 2016b). Recent studies have shown that the LUC from pasture to sugarcane depletes soil organic carbon (SOC) stocks (Mello et al., 2014; Franco et al., 2015) and increases soil susceptibility to compaction due to heavy and intense traffic during mechanical harvest and transport (Braunack and McGarry, 2006; Lozano et al., 2013; Souza et al., 2014). Therefore, soil compaction has been identified as the main concern in modern sugarcane production systems in Brazil (Lozano et al., 2013; Souza et al., 2014) and has been characterized by increases in bulk density, leading to a reduction in macroporosity and water infiltration (Braunack and McGarry, 2006; Castro et al., 2013; Souza et al., 2014). Furthermore, these physically and structurally degraded soils decrease root growth and sugarcane yield (Otto et al., 2011; Baquero et al., 2012; Souza et al., 2014).

Impacts of sugarcane production on soil physical and structural quality have been traditionally assessed using quantitative soil physical properties such as bulk density, soil porosity, soil resistance to penetration, aggregate stability and macroaggregation that are indirectly related to soil structure (Otto et al., 2011; Lozano et al., 2013; Souza et al., 2014). However, measurements of these soil properties are relatively time consuming and each sample provides an indication of the structural condition only at the point where it was taken within the soil profile (Newell-Price et al., 2013). Alternatively, visual methods of assessment of soil structure are characterized as simple, inexpensive, reliable and accurate, easy to perform, capable of producing results quickly and being easily understood by researchers, advisers and farmers (Ball et al., 2007; Guimarães et al., 2011; Askari et al., 2013; Giarola et al., 2013; Pulido Moncada et al., 2014). To make the assessment of soil physical quality simpler, spade methods based on the assessment of topsoil $(0-25 \mathrm{~cm})$ have been widely developed. This includes the "Visual Soil Assessment" (VSA) method developed by Shepherd (2009) and the "Visual Evaluation of Soil Structure" (VESS) method described by Ball et al. (2007) and improved by Guimarães et al. (2011).

The VESS method was developed from the Peerlkamp method (Ball et al., 2007) and has been recognized as one of the simplest methods to employ while still including a variety of soil structure and rooting assessments (Guimarães et al., 2013) in a way that Ball et al. (2013) concluded it can evaluate more than soil structural quality, but VESS can give a first approximation of overall soil quality. The VESS method involves taking an undisturbed soil sample, breaking it up and visually assessing the size, shape, porosity and strength of aggregates, presence and state of roots and soil color (Ball et al., 2007; Guimarães et al., 2011). These soil characteristics are integrated into a single numeric score (Sq - structural quality) that ranges from 1 (good structural quality) to 5 (poor structural quality) that can subsequently be subjected to statistical analysis for decision making (Munkholm et al., 2013). Another distinctive feature of VESS is its ability to distinguish between topsoil layers width different structural characteristics. Giarola et al. (2010) and Guimarães et al. (2011, 2013) stressed the importance of evaluating soil layers individually rather than giving only a weighted average score, because doing so can improve the choice of management practices adopted to preserve or improve overall structural soil quality.

In recent years, VESS has been used to evaluate soil structure and soil quality under different land use and soil management (e.g., Imhoff et al., 2009; Giarola et al., 2010, 2013; Askari et al., 2013; Guimarães et al., 2013; Mueller et al., 2013; Munkholm et al., 2013; Cui et al., 2014; Pulido Moncada et al., 2014; Abdollahi et al., 2015). However, we are not aware of any studies using VESS for evaluating soil structure changes induced by sugarcane expansion in Brazilian tropical soils. Therefore, our objective was to apply the VESS method for assessing soil structural quality changes associated with a LUC sequence (i.e., native vegetation to pasture to sugarcane) at three field-sites across central-southern Brazil. We tested the hypotheses that (i) the VESS method is able to efficiently detect soil structure changes due to LUC and is a suitable indicator of soil quality in areas under sugarcane expansion in Brazil; (ii)

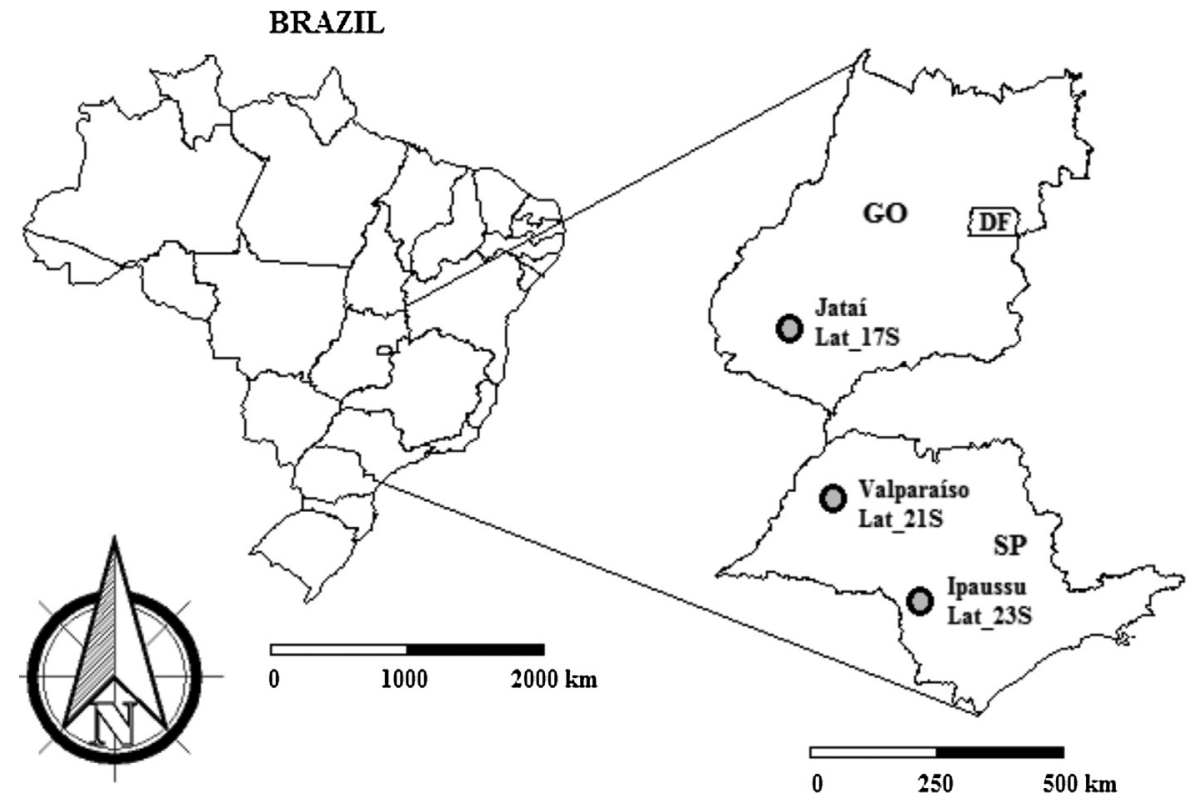

Fig. 1. Geographic location of study sites in central-southern Brazil. 
Table 1

Historical of the land-use change and management practices for each studied site.

\begin{tabular}{|c|c|c|}
\hline Site $^{\mathrm{a}}$ & Land use & Description \\
\hline \multirow[t]{3}{*}{ Lat_17S } & $\begin{array}{l}\text { Native } \\
\text { vegetation }\end{array}$ & Cerradão vegetation (Cerrado Biome - Brazilian savanna) \\
\hline & Pasture & $\begin{array}{l}\text { Land-use conversion from native vegetation to pasture occurred in } 1980 \text {. The pasture was composed of tropical grasses of the Brachiaria genus } \\
\text { and supported } 1.5 \mathrm{AU} \mathrm{ha}{ }^{-1} \text { full year. }\end{array}$ \\
\hline & Sugarcane & $\begin{array}{l}\text { Sugarcane was cropped over part of the pasture in } 2009 \text {. At that time the soil was prepared by plowing and disking. At sampling time sugarcane } \\
\text { field was under reformation (chiseling and disking). Fertilizers are applied annually. The sugarcane was mechanically harvested using a } \\
\text { harvester }(\approx 20 \mathrm{Mg}) \text { and transported by a tractor + trailer }(\approx 10+20 \mathrm{Mg}) \text {. Sugarcane production has no used controlled traffic system. }\end{array}$ \\
\hline \multirow[t]{3}{*}{ Lat_21S } & $\begin{array}{l}\text { Native } \\
\text { vegetation }\end{array}$ & Semideciduous Seasonal Forest, comprising a transition between the Atlantic forest and Cerrado vegetation \\
\hline & Pasture & $\begin{array}{l}\text { Land-use conversion from native vegetation to pasture occurred in } 1980 \text {. The pasture was composed of tropical grasses of the Brachiaria genus, } \\
\text { and supported } 2 \mathrm{AU} \mathrm{ha}^{-1} \text { full year. }\end{array}$ \\
\hline & Sugarcane & $\begin{array}{l}\text { Sugarcane was cropped over part of the pasture in } 2010 \text {. At that time the soil was prepared by plowing and disking. At sampling time sugarcane } \\
\text { was in full growth close to harvest of the fourth ratoon cropping of its cycle. Fertilizers are applied annually. The sugarcane was mechanically } \\
\text { harvested without controlled traffic system using sing similar machines those described for Lat_17S. }\end{array}$ \\
\hline \multirow[t]{3}{*}{ Lat_23S } & $\begin{array}{l}\text { Native } \\
\text { vegetation }\end{array}$ & The local vegetation is similar that described for Lat_21S site. \\
\hline & Pasture & $\begin{array}{l}\text { Land-use conversion from native vegetation to pasture occurred in } 1979 \text {. The pasture was composed of tropical grasses of the Cynodon genus } \\
\text { and supported } 1 \mathrm{AU} \mathrm{ha}^{-1} \text { full year. }\end{array}$ \\
\hline & Sugarcane & $\begin{array}{l}\text { Sugarcane was cropped over part of the pasture at the beginning of the 1990s. At that time soil was prepared by plowing and disking. At } \\
\text { sampling time the sugarcane was in its initial growth of the fifth ratoon cropping of its cycle. Fertilizers are applied annually. The sugarcane has } \\
\text { been mechanically harvested since } 2003 \text { without controlled traffic system using similar machines those described for Lat_17S. }\end{array}$ \\
\hline
\end{tabular}

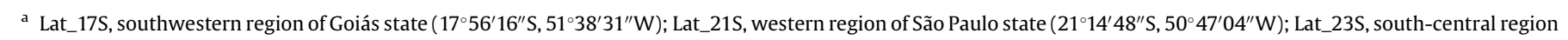
of São Paulo state $\left(23^{\circ} 05^{\prime} 08^{\prime \prime} \mathrm{S}, 49^{\circ} 37^{\prime} 52^{\prime \prime} \mathrm{W}\right)$.

VESS Sq score is negatively affected by LUC from native vegetation to pasture to sugarcane and, (iii) VESS Sq score is correlated with quantitative soil physical properties.

\section{Material and methods}

\subsection{Study sites}

The study was carried out in central-southern Brazil region (Fig. 1), which is considered the primary sugarcane-producing area in the world. Three strategic and representative sites were chosen along a transect of approximately $1000 \mathrm{~km}$ across this region: (i) Lat_17S: located near to Jataí city in the southwestern region of Goiás state (Lat.: $17^{\circ} 56^{\prime} 16^{\prime \prime} \mathrm{S}$; Long.: $51^{\circ} 38^{\prime} 31^{\prime \prime} \mathrm{W}$ ) with a mean altitude of $800 \mathrm{~m}$; this area represents the most important region of sugarcane expansion within the Cerrado Biome; (ii) Lat_21S: located near to Valparaíso city in the western region of São Paulo state (Lat.: $21^{\circ} 14^{\prime} 48^{\prime \prime}$ S ; Long.: $50^{\circ} 47^{\prime} 04^{\prime \prime} \mathrm{W}$ ) with a mean altitude of $425 \mathrm{~m}$ and (iii) Lat_23S, located near to Ipaussu city in the central-south region of São Paulo state (Lat.: $23^{\circ} 05^{\prime} 08^{\prime \prime}$ S; Long.: $49^{\circ} 37^{\prime} 52^{\prime \prime}$ W), with a mean altitude of $630 \mathrm{~m}$. The latter two sampling areas are representative of the largest sugarcane-producing region of Brazil.

The climate at all three sites is characterized by rainfall concentrated in the spring and summer (October to April), while the dry season occurs in the autumn and winter (May to
September). According to Köppen-Geiger's system, the climate is classified as Awa type (mesothermal tropical) at Lat_17S, Aw type (humid tropical) at Lat_21S and Cwa type (tropical) at Lat_23S.

\subsection{Land-use change sequence}

A synchronic approach was used at each site (Lat_17S; Lat_21S; Lat_23S) and was composed of three land uses: native vegetation, pasture and sugarcane. Currently, this represents the most common LUC sequence in Brazil under sugarcane production. The synchronic approach was chosen to represent potential longterm changes occurring in areas under sugarcane expansion for ethanol production. Adjacent land-use areas were chosen and sampled to minimize uncontrolled factors (e.g., climate, topography and soil variations).

The land-use history and primary management practices implemented at each site and land use system are shown in Table 1 . The soils are typical of the Brazilian tropical area, highly weathered with a predominance of the $1: 1$ clay mineral (kaolinite), iron oxides (goethite and hematite) and aluminum oxide (gibbsite) in the clay-size fraction. The classification of the soils, using criteria outlined by the USDA Soil Taxonomy (Soil Survey Staff, 2014), is presented in Table 2. Further details regarding soil characteristics and LUC history of the studied sites are available in Cherubin et al. (2015).

Table 2

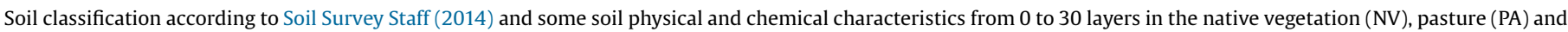
sugarcane (SC) at the studied sites.

\begin{tabular}{|c|c|c|c|c|c|c|c|c|c|}
\hline Site & Land use & Soil classification & Soil structure type ${ }^{\mathrm{b}}$ & $\begin{array}{l}\text { Sand } \\
\mathrm{g} \mathrm{kg}^{-1}\end{array}$ & Silt & Clay & $\mathrm{SOC}^{\mathrm{a}}$ & $\mathrm{pH}_{\mathrm{CaCl} 2}$ & Drainage status $^{\mathrm{b}}$ \\
\hline \multirow{3}{*}{ Lat_17S } & NV & clayey Anionic Acrudox & single grain & 605 & 67 & 328 & 13.2 & 3.8 & Well drained \\
\hline & PA & loamy Typic Hapludox & subangular blocks & 820 & 28 & 152 & 8.0 & 3.8 & Well drained \\
\hline & SC & clayey Anionic Acrudox & single grain & 585 & 75 & 340 & 10.1 & 5.0 & Strongly drained \\
\hline \multirow[t]{3}{*}{ Lat_21S } & NV & loamy Typic Rhodudalf & subangular blocks & 753 & 79 & 178 & 16.9 & 6.2 & Moderately drained \\
\hline & PA & fine-loamy Typic Kandiudult & subangular blocks & 756 & 68 & 176 & 10.1 & 3.9 & Moderately drained \\
\hline & SC & loamy Typic Hapludalf & subangular blocks & 766 & 75 & 159 & 9.8 & 5.0 & Moderately drained \\
\hline \multirow[t]{3}{*}{ Lat_23S } & NV & clayey Rhodic Hapludox & angular and subangular blocks & 192 & 148 & 660 & 34.8 & 3.7 & Well drained \\
\hline & PA & clayey Rhodic Kandiudox & angular and subangular blocks & 222 & 188 & 590 & 28.9 & 4.6 & Well drained \\
\hline & SC & clayey Rhodic Hapludox & subangular blocks & 227 & 122 & 651 & 19.0 & 5.4 & Well drained \\
\hline
\end{tabular}

a SOC: soil organic carbon.

b Structure type and drainage status were classified according to described by Santos et al. (2013). 


\subsection{Visual Evaluation of Soil Structure measurements}

Soil sampling consisted of taking four samples at each land-use site (i.e., totaling 36 soil samples). Sampling points were positioned in representative locations within each land use sampled. In native vegetation areas we avoided sampling close to ant or termite nests, burrows of wild animals and big trees. In pasture areas, which were continuously and uniformly grazed, our major caution was to avoid sampling on the preferential cattle trampling paths, where the soil is much more compacted. Except at Lat_17S where the soil had been recently tilled for sugarcane replanting, all sampling points in sugarcane fields were located within the inter-row position, which is homogeneously tracked during harvest operations.

The VESS assessment and signature of scores were completed as described by Guimarães et al. (2011). At each sampling core, a minitrench $(30 \times 30 \times 30 \mathrm{~cm}$ in size $)$ was dug out and then, using a spade, an undisturbed sample $\left(20 \times 10 \times 25 \mathrm{~cm}\right.$ deep $-5000 \mathrm{~cm}^{3}$ volume $)$ was collected and transferred to a plastic tray. The soil water content at the moment of VESS assessment for native vegetation, pasture and sugarcane areas at each site was, respectively: 0.18, 0.09 and $0.19 \mathrm{~g} \mathrm{~g}^{-1}$ at Lat_17S; $0.13,0.12$ and $0.11 \mathrm{~g} \mathrm{~g}^{-1}$ at Lat_21S and $0.28,0.31$ and $0.28 \mathrm{~g} \mathrm{~g}^{-1}$ at Lat_23S. The soil evaluation included manual breakdown of soil aggregates along its fracture lines, identification of layers of contrasting structure, measurement of layer thickness and assignment of a score by comparing the structure of the sample with the VESS chart, which contains descriptions and pictures of each proposed soil structure quality, according to described by Guimarães et al. (2011).

Since distinct layers were identified and a score was assigned for each layer identified according to the standard chart description, a final weighted score for each soil sample was calculated using Eq. (1).

$\operatorname{VESS}_{\mathrm{Sq}}=\sum_{i=1}^{n} \frac{S q i T i}{T T}$

where, VESS $\mathrm{Sq}_{\text {is }}$ the overall VESS score, Sqi and Ti are respectively the score and thickness of each identified soil layer, and TT is the total thickness of soil sample.

Two additional strategies of scoring were also used: first, a weighted average of the Sq score was taken for the top $(0-10 \mathrm{~cm})$ and bottom $(10-25 \mathrm{~cm})$ soil layers at each site, and second, an overall Sq was taken using the thickness and Sq scores of the naturally formed first and second soil layers.

The interpretation of VESS scores was conducted according to Ball et al. (2007), which is based on requirements to change management practices to preserve soil structural quality: $\mathrm{Sq}=1$ and $S q=2$, good soil structural quality, requiring no changes in management practices; $\mathrm{Sq}=3$, adequate soil structural quality; however there is need for improved soil management to avoid a further decline in soil quality (Ball et al., 2017). Therefore, we considered $\mathrm{Sq}=3$ as a provisional threshold from which soil starts to decline its structural quality; $\mathrm{Sq}=4$ and $\mathrm{Sq}=5$, indicate poor soil structural quality, requiring urgent remedial management practices.

\subsection{Relationship among VESS scores and quantitative soil physical properties}

VESS is not a soil physical property but rather, it is a semiquantitative measurement that can be used as an indicator of soil structural quality. Thus, the VESS Sq score should be related to quantitative soil physical properties (e.g., bulk density; soil porosity, soil resistance to penetration) routinely used for studying soil structure in the laboratory and the field. In order to establish functional relationships between VESS scores and soil physical properties, undisturbed soil samples $\left(100 \mathrm{~cm}^{3}\right)$ were collected at the same sampling point and time of the VESS assessments. Soil bulk density (BD) was calculated by the ratio between soil dry mass and core volume; macroporosity (MaP) was computed as the difference between soil water content at saturation and soil water content at $-6 \mathrm{kPa}$ soil water potential; and soil water storage capacity (SWSC) index, obtained as the ratio between water content at field capacity $(-10 \mathrm{kPa}$ soil water potential) and total porosity. Also, soil resistance to penetration (SRP) measurements (five replications) were taken around mini-trenches to a depth of $30 \mathrm{~cm}$ using a digital penetrometer (PenetroLOG ${ }^{\mathbb{R}}$ ) with cone angle of $30^{\circ}$ and diameter of $7.94 \mathrm{~mm}$.

\subsection{Statistical analyses}

The normality of the raw data was tested using a Shapiro-Wilk's test $(p>0.05)$ and a descriptive analysis was performed through the Statistical Analysis System - SAS v.9.3 (SAS Inc., Cary, USA) software. Comparisons among land use types (native vegetation, pasture and sugarcane) were performed for VESS scores (0-10-, $10-25$ - and $0-25-\mathrm{cm}$ layers) using one-way ANOVA with land use type as the main factor and sites considered as blocks and treated as a random variable. If ANOVA was significant $(p<0.05)$ average values were compared using Tukey's test $(p<0.05)$. Linear correlations between VESS and quantitative soil physical attributes were verified within each study site by Pearson's correlation analysis using PROC CORR procedure available in SAS.

\section{Results and discussion}

\subsection{VESS sensitivity to detect LUC effects on soil structural quality}

\subsubsection{VESS assessment}

The VESS method was capable of assessing soil structural quality changes under a wide textural range (15-66\% clay content) in the Brazilian tropical soils studied. The VESS assessment took about 20-25 min from digging out the mini-trench to assigning the final score. It was more difficult to extract and breakdown samples from sugarcane soils indicating signs of soil compaction and damaged soil structure. It is also important to collect samples when soil moisture is close to field capacity, in order to minimize the physical effort associated with digging the mini-trench, extracting, and manipulating the samples as previously reported

\section{Table 3}

Descriptive statistic of overall VESS scores for 0-25 cm layer in the native vegetation $(\mathrm{NV})$, pasture (PA) and sugarcane (SC) at three sites in central-southern Brazil.

\begin{tabular}{|c|c|c|c|c|c|c|c|c|c|}
\hline \multirow[t]{3}{*}{ Land use } & \multicolumn{9}{|c|}{ Statistical parameters ${ }^{a}$} \\
\hline & \multicolumn{4}{|c|}{ Values } & \multirow[t]{2}{*}{ SD } & \multicolumn{3}{|c|}{ Coefficients } & \multirow[t]{2}{*}{ W test ${ }^{*}$} \\
\hline & Min & Mean & Median & Max & & $\mathrm{CV}$ & Cs & $\mathrm{Ck}$ & \\
\hline \multicolumn{10}{|l|}{ Lat_17S } \\
\hline NV & 1.30 & 1.81 & 1.83 & 2.28 & 0.43 & 23.53 & -0.19 & -1.46 & $0.99^{\mathrm{ns}}$ \\
\hline PA & 1.61 & 2.00 & 2.01 & 2.36 & 0.31 & 15.35 & -0.24 & 1.51 & $0.95^{\mathrm{ns}}$ \\
\hline SC & 1.80 & 2.49 & 2.65 & 2.85 & 0.47 & 18.84 & -1.71 & 3.14 & $0.82^{\mathrm{ns}}$ \\
\hline \multicolumn{10}{|l|}{ Lat_21S } \\
\hline NV & 1.52 & 1.80 & 1.81 & 2.08 & 0.23 & 13.02 & -0.06 & 0.05 & $0.99^{\mathrm{ns}}$ \\
\hline PA & 2.46 & 2.91 & 3.00 & 3.18 & 0.32 & 11.01 & -1.33 & 1.50 & $0.89^{\mathrm{ns}}$ \\
\hline SC & 3.39 & 3.66 & 3.63 & 4.00 & 0.26 & 6.97 & 0.71 & 1.08 & $0.97^{\mathrm{ns}}$ \\
\hline \multicolumn{10}{|l|}{ Lat_23S } \\
\hline NV & 1.74 & 2.52 & 2.68 & 3.00 & 0.56 & 22.29 & -1.26 & 1.13 & $0.90^{\mathrm{ns}}$ \\
\hline PA & 2.92 & 3.19 & 3.15 & 3.40 & 0.23 & 7.33 & 0.06 & -4.54 & $0.90^{\mathrm{ns}}$ \\
\hline SC & 2.87 & 3.26 & 3.08 & 4.00 & 0.51 & 15.66 & 1.71 & 3.02 & $0.82^{\mathrm{ns}}$ \\
\hline
\end{tabular}

a SD: standard deviation; CV (\%): coefficient of variation; Cs: coefficient of skewness; Ck: coefficient of kurtosis.

" W test: Shapiro-Wilk's test for normal distribution, where: (ns) non-significant by $p<0.05$, indicating that the hypothesis of data are normally distributed was not rejected. Number of observations $(n)=4$ ". 
by Imhoff et al. (2009),Giarola et al. (2013) and Pulido Moncada et al. (2014). The step-by-step recommendations, pictures and criteria for Sq score differentiation available on the VESS chart properly enabled the identification of soil layers with different soil structural conditions. The shape of aggregate (approx. $1.5 \mathrm{~cm}$ diameter) was an important criterion for distinguishing between two scores when visual differentiation was not clear, especially for
Sq scores between 3 and 4 (Guimarães et al., 2011). We stress that some training might be required by the user when assessing the soil using VESS. The visual evaluations were performed by the same person in order to keep the same assessment pattern and thus avoid potential Sq variability induced by different operators. Despite these limitations, several studies have shown that VESS scores have good reproducibility and that assessments can be

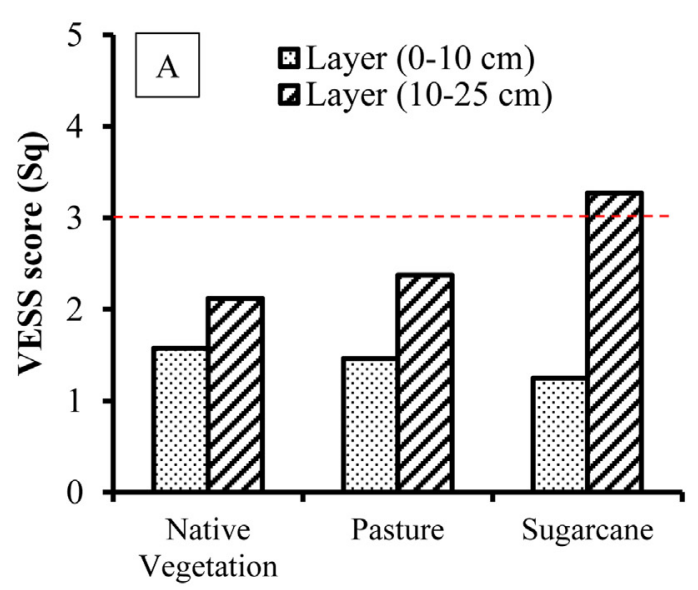

Lat_17S

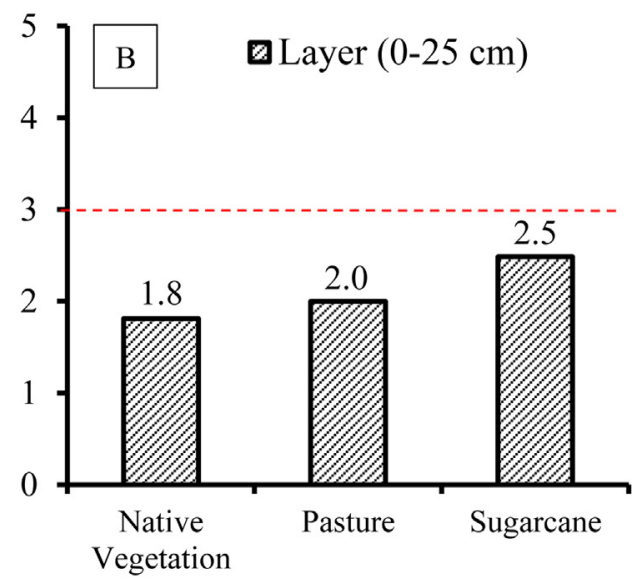

Lat_21S
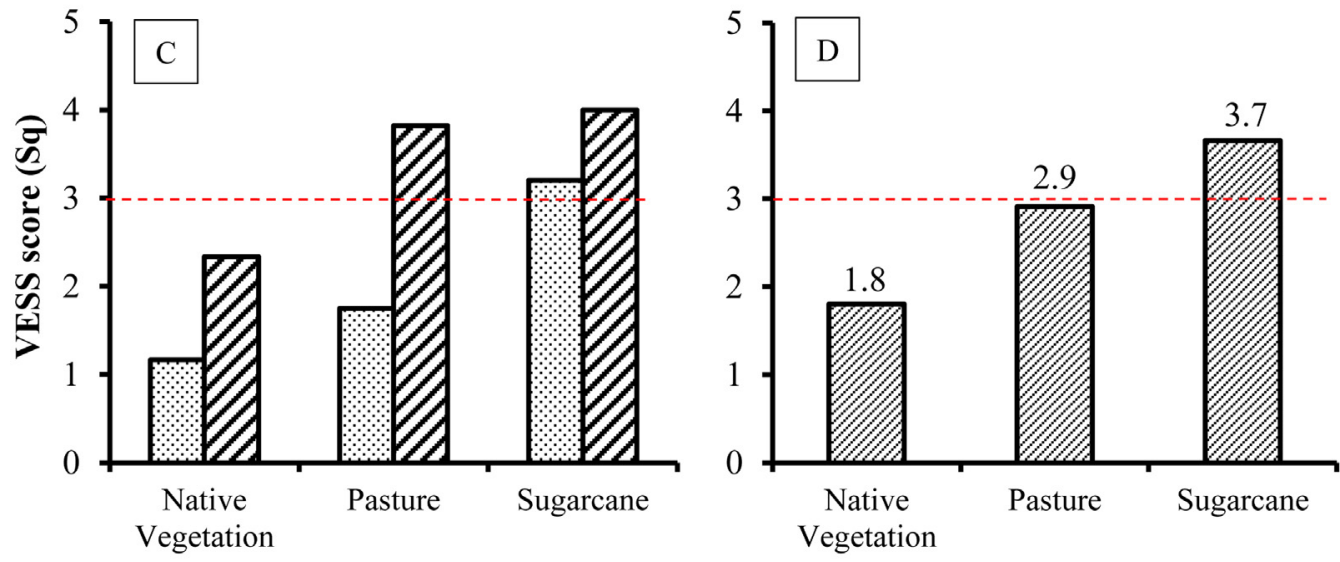

Lat_23S
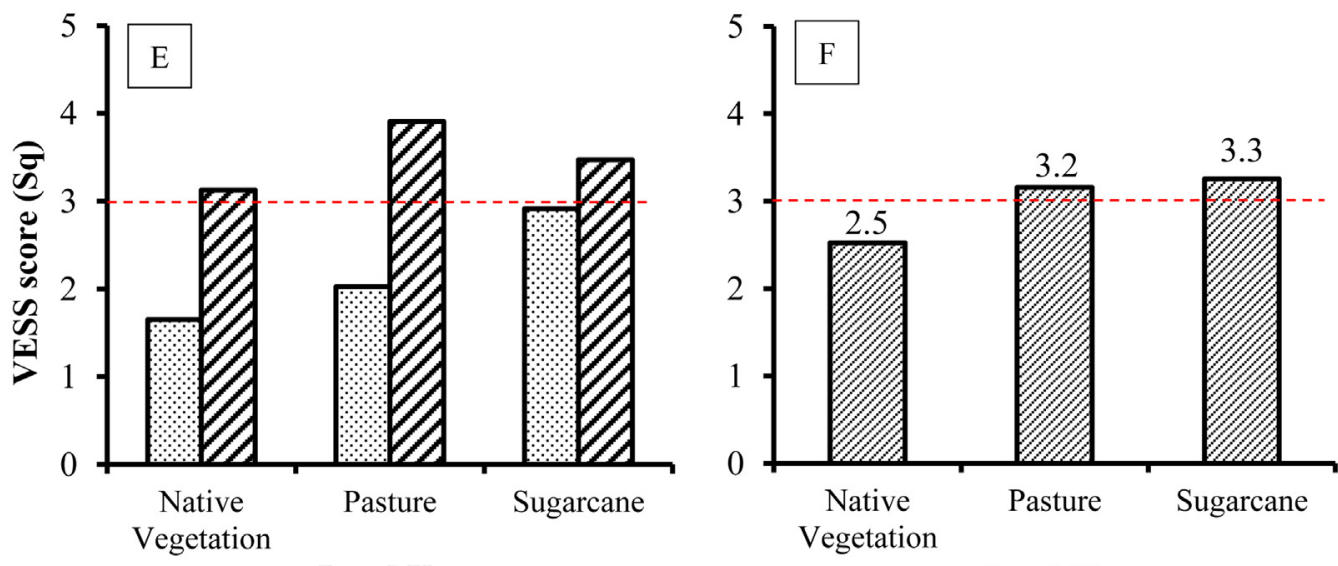

Land Use

Land Use

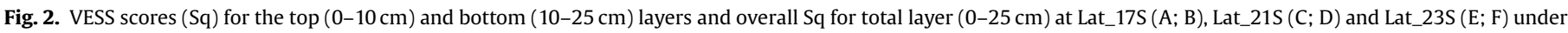

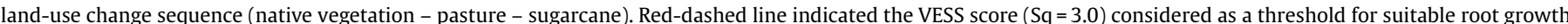


accurately made by different, trained operators (Ball et al., 2007; Cui et al., 2014).

\subsubsection{VESS Sq scores}

The overall VESS Sq scores ranged from 1.3 (native vegetation) and 4.0 (sugarcane), indicating a variation from good to poor soil structural quality among land uses (Table 3). Mean and median values had small differences and coefficient of variation values were below $25 \%$. The normality of data was confirmed by ShapiroWilk's test $(p>0.05)$. The VESS method was sensitive to soil structure changes induced by LUC for sugarcane production (Fig. 2; Fig. 3). Overall, conversion from native vegetation to pasture and then to sugarcane decreased soil structural quality for all soil layers (Fig. 2). When the three sites were analyzed together (regional scale), overall VESS Sq scores had a statistically significant increase from $\mathrm{Sq}=2.0$ in native vegetation to $\mathrm{Sq}=2.7$ in pasture and then to $\mathrm{Sq}=3.1$ in sugarcane fields (Fig. 3). We also identified an increasing trend in VESS scores from the top layer $(0-10 \mathrm{~cm}$ thickness) to the bottom layer (10-25 cm thickness) (Fig. 2; Fig. 3), indicating an increasing level of degradation in deeper layers. Guimarães et al. (2013) reasoned that assigning scores to individual layers provides information that is more detailed and, therefore, allows better management decision making than when only using a weighted average as described by Ball et al. (2007). Using this approach,
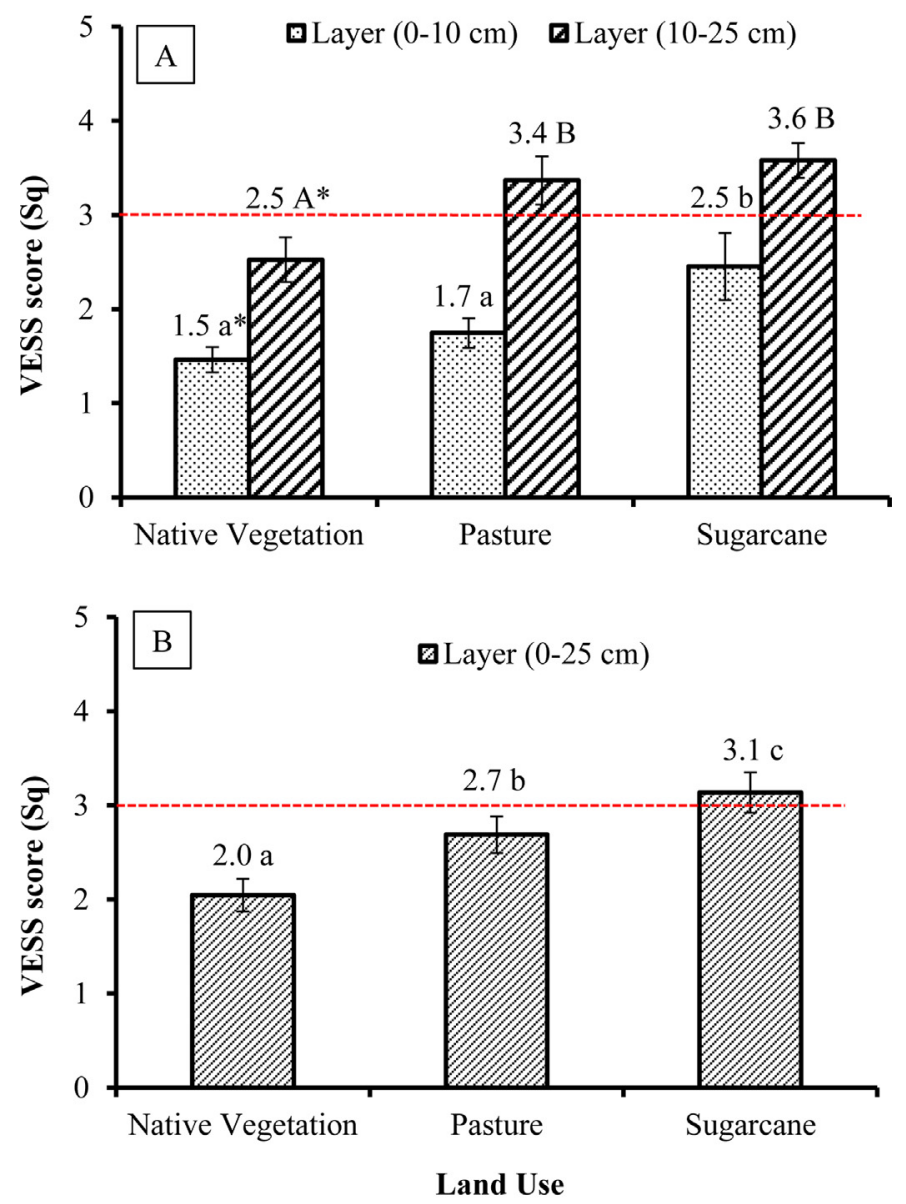

Fig. 3. VESS scores $(\mathrm{Sq})$ for the top $(0-10 \mathrm{~cm})$ and bottom $(10-25 \mathrm{~cm})$ layers $(\mathrm{A})$ and overall Sq for total layer $(0-25 \mathrm{~cm})(B)$ in regional scale under land-use change sequence (native vegetation - pasture - sugarcane). Bars represent the standard error of the mean. Dashed lines indicate the VESS score $(\mathrm{Sq}=3)$ considered as a threshold for suitable root growth. *Mean values within each soil layer followed by the same letter (small or upper case) do not differ among themselves according to Tukey's test $(p<0.05)$. users can identify specific layers for sampling in case additional samples for quantitative analysis of soil quality indicators are desired (Guimarães et al., 2013).

Native vegetation soils, regardless of soil layer, have greater structural quality $(\mathrm{Sq}<3.0$ ), supporting a suitable environment for root system growth and the exploitation of deeper soil layers. For pasture and sugarcane soils, poorer structural quality (Sq > 3.0) was identified, mainly in the bottom layer $(10-25 \mathrm{~cm})$ at Lat_21S and Lat_23S, suggesting that management practice changes are needed to alleviate soil compaction. Our regional scale VESS assessment showed for sugarcane an overall score $(\mathrm{Sq}=3.1)$ that was very close to the limit ( $\mathrm{Sq}=3.0$ ) suggested by Ball et al. (2007), but it was even worse (i.e., average $\mathrm{Sq}=3.5$ ) in areas in the end of five-year sugarcane cycle (i.e., Lat_21S - $4^{\circ}$ ratoon and Lat_23S - $5^{\circ}$ ratoon). These results confirm that current soil and crop management practices being used for sugarcane production are fostering a dangerous decline in soil structural quality and its consequent deleterious effects on sugarcane growth, development, and productivity. These results are supported by several other studies that show that current management practices can lead to soil compaction, which negatively affects sugarcane root system development and consequently, reduced yields (Braunack and McGarry, 2006; Otto et al., 2011; Baquero et al., 2012; Souza et al., 2014).

\subsubsection{Thickness of the soil layers identified by VESS}

The thickness of the top and bottom layers and their respective Sq scores are shown in Fig. 4. A thicker soil top layer and lower VESS scores (i.e., better soil structural quality) were identified in native vegetation than in pasture or sugarcane. Greater thickness and higher $\mathrm{Sq}$ scores were observed in the bottom layer of sugarcane fields. A thicker bottom layer with lower soil structural quality suggests a strong limitation for sustainable yields using current sugarcane production practices. The differences in both thickness and VESS scores induced by LUC can be clearly seen in Fig. 5. Overall, native vegetation soils had a top layer that was $35 \%$ or $50 \%$ thicker than in pasture or sugarcane soils, respectively (Fig. 4D).

The greater inputs of soil organic matter (SOM) and biological activity associated with absence of soil tillage and management are key factors for maintaining a thicker layer $(\bar{x} 10.4 \mathrm{~cm})$ of better soil structural quality $(\bar{x} \mathrm{Sq}=1.2)$ under native vegetation. Recently, Franco et al. (2015) verified that native vegetation had greater SOC stocks (0-30 cm layer) compared to pasture (average -26\%) and sugarcane (average $-36 \%$ ) soils at these same sampling sites. Furthermore, Franco et al. (2016) found significantly greater macrofauna diversity in these native vegetation soils than in pasture and sugarcane soils. It was confirmed by field observations during VESS assessments indicated a great presence of earthworm burrows and evenness of root distribution in native vegetation soils. Organic carbon inputs associated with soil biota and root activity act as cementing agents throughout the soil aggregation process, gradually resulting in the formation of organic-mineral complexes (primary particles) that slowly form micro- and then macroaggregates (Tisdall and Oades, 1982). Soil aggregates physically protect some SOM fractions, resulting in carbon pools with longer turnover times. This increase in $\mathrm{C}$ turnover time enables the organization of more complex and stable soil structure under native vegetation areas (Elliott, 1986; Six et al., 1998). Furthermore, the absence of tillage avoids disruption of aggregates and exposure of occlude SOM, that can ultimately lead to SOM decomposition.

Long-term conversion from native vegetation to extensive pasture induced soil structure alterations in the sampled soil profile. We found a thinner layer $(\bar{x} 6.8 \mathrm{~cm})$ of good soil structural 

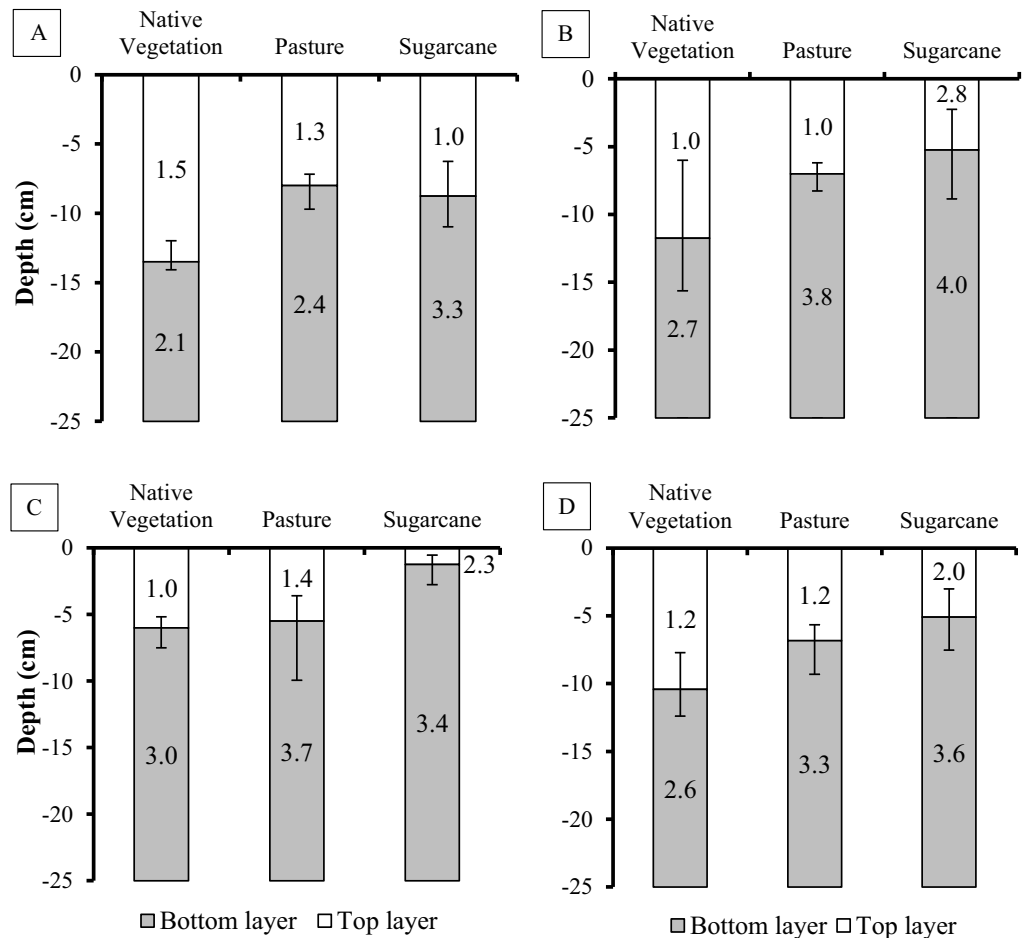

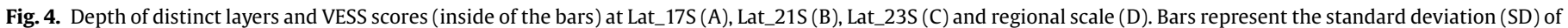
the mean, where upper and lower sides of the bars are relative to top and bottom layer depths, respectively.

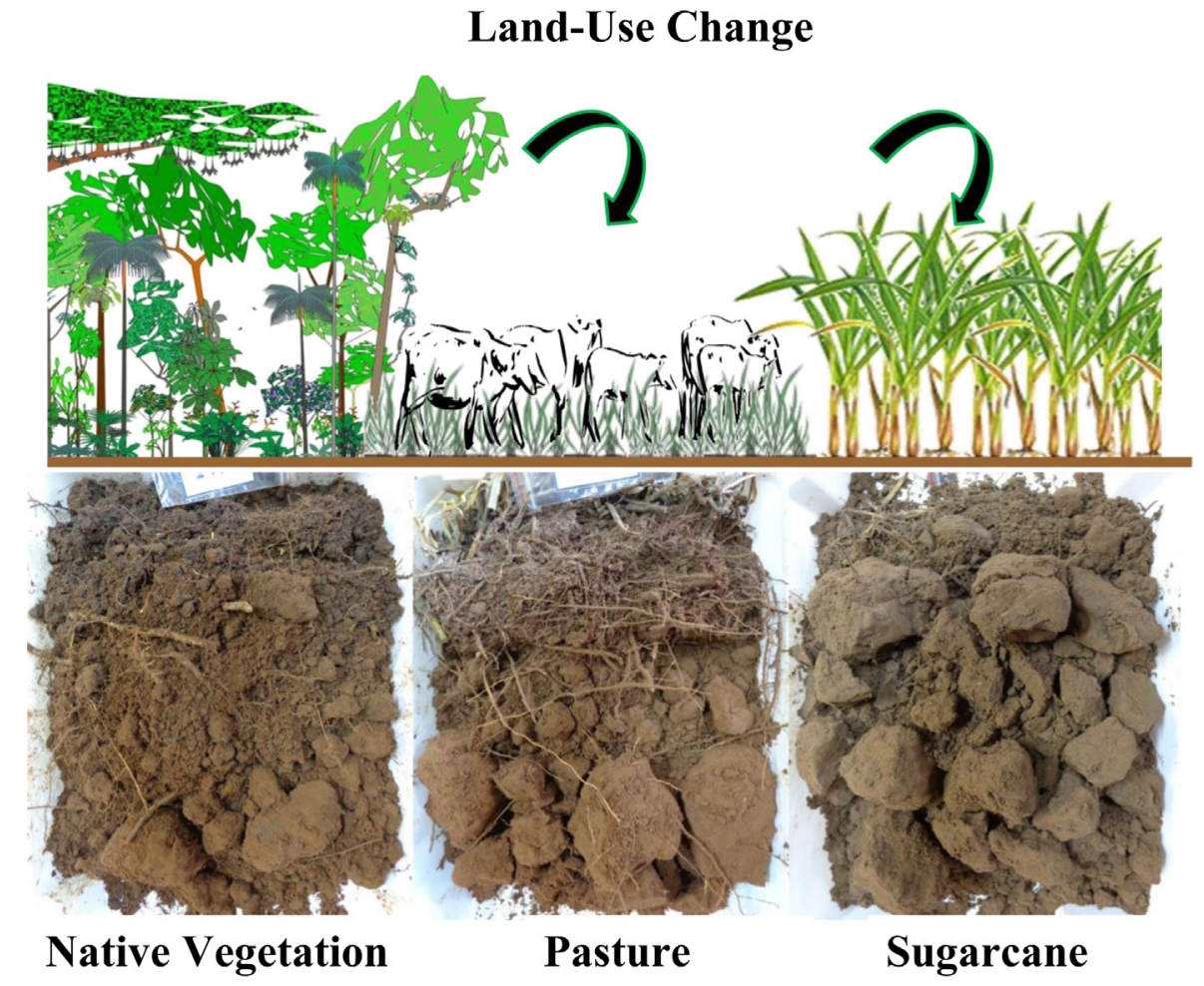

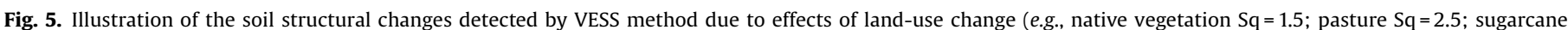
$\mathrm{Sq}=4.0$ ) in central-southern Brazil.

quality $(\bar{x} \mathrm{Sq}=1.2)$ only associated with the rhizosphere zone (Fig. 5) overlying a compacted and thicker soil layer. The vigorous root systems of tropical grasses (e.g., the Brachiaria and Cynodon genera) can increase aggregate stability and improve soil structural quality (Vezzani and Mielniczuk, 2011; Fonte et al., 2012). Large root systems promote high $\mathrm{C}$ inputs and act on the formation and stabilization of soil structure. Greater C stock within upper soil layers was confirmed by Franco et al. (2015), who reported average SOC stock decreases of $6 \%$ from 0 to 10 to 10 to $20 \mathrm{~cm}$ layer and $18 \%$ from 0 to 10 to 20 to $30 \mathrm{~cm}$ layer in these pasture sites. Roots 
release a variety of exudates that have a cementing effect on soil particles and they can physically influence microaggregate formation via the compressing action of growing roots and in the entanglement of soil particles to form and stabilize macroaggregates (Tisdall and Oades, 1982; Six et al., 2004; Bronick and Lal, 2005). Roots also increase wet-dry cycling of adjacent soil, alter the ionic and osmotic balance in the rhizosphere through nutrient uptake and rhizodeposition and host a large population of microand macroorganisms that contribute to SOC and soil aggregation (Tisdall and Oades, 1982; Six et al., 2004; Bronick and Lal, 2005). In contrast, continuous cattle trampling and inadequate pasture management are the major drivers for soil compaction in pasturelands (Newell-Price et al., 2013; Cui et al., 2014). Soil compaction limits growth and depth penetration of roots, decreasing deeper allocation of SOC and its potential improvement on soil structural quality. It results in a thicker bottom soil layer $(\bar{x}$ $18.2 \mathrm{~cm}$ ) of poor structural quality $(\bar{x} \mathrm{Sq}=3.3$ ).

In sugarcane fields, a thinner soil surface layer $(\bar{x} 5.1 \mathrm{~cm})$ with good structural quality $(\bar{x} \mathrm{Sq}=2.0)$ and consequently a thicker bottom layer $(\bar{x} 19.9 \mathrm{~cm})$ of poor soil structural quality $(\bar{x} \mathrm{Sq}=3.6)$ can be associated with soil tillage operations performed during the establishment (land-use conversion) and replanting of sugarcane (Cherubin et al., 2016b), SOC and macrofauna losses (Franco et al., $2015,2016)$ and intensive machinery traffic under favorable conditions for soil compaction (although we have no data of machinery traffic in our sites, this situation is frequently observed in Brazilian sugarcane areas). A thinner soil layer with good soil structural quality (lower Sq score) implies a reduced soil volume exploited by the sugarcane root system (Otto et al., 2011; Souza et al., 2014). Under weather condition in central-southern Brazil, especially during dry periods, a more fragile and shallow root system makes sugarcane plants more susceptive to chemical and physical stresses that can lead to a decline in yield and the need for premature replanting operations. The soil tillage operations provide an intensive soil disturbance, inducing SOC losses to the atmosphere (Silva-Olaya et al., 2013; Mello et al., 2014). In addition, sugarcane reformation is very expensive and requires appropriate weather to be carried out in an agronomically successful manner. Therefore, soil structural degradation decreases both environmental and economic sustainability of sugarcane production. The thin surface layer of good soil structure observed in sugarcane fields (Fig. 4; Fig. 5) may be related to the positive effects of maintaining sugarcane straw on the soil surface. These results are supported by Franco et al. (2015), who reported reduction of SOC in deeper layers in these same sugarcane sites. Dalchiavon et al. (2013) also verified that maintenance of sugarcane straw on the soil surface increases SOC stocks, decreases bulk density and soil resistance to penetration, and improves sugarcane yield.

Despite the differences between soils and length of sugarcane cultivation, a comparison of sugarcane fields at the different study sites (Fig. 6) indicated that VESS Sq scores increased from sugarcane replanting (Lat_17A) through initial growth (Lat_23S) to full growth (Lat_21S). Tillage operations conducted during planting or replanting (plowing and disking) promote soil disturbance and consequently alleviate soil compaction. Therefore, just after those operations VESS scores are lower, indicating better soil structural quality and good soil physical conditions for sugarcane growth. However, our data suggest that tillage performed for sugarcane replanting had a short-term effect on soil structure. Soil tillage operations promote disruption of macroaggregates favoring SOC losses (Six et al., 1998, 2004) and inducing an increase in soil compaction over time (Castro et al., 2013). Its deleterious effects are further magnified by successive machinery operations used during the sugarcane production season (Lozano et al., 2013; Souza et al., 2014). We emphasize that these results that show VESS score changes during the sugarcane cycle should be interpreted carefully, as our dataset was collected from different sites under distinct soil and weather conditions. Additional studies for evaluating impacts of sugarcane management on soil structure assessed by VESS should be carried out through the whole sugarcane cycle (about five years). Furthermore, subsoil compaction in sugarcane fields should also be evaluated using the field methodology such as SubVESS, proposed by Ball et al. (2015). The SubVESS is a methodology for assessing soil structural quality below spade depth, i.e. from 25 to $200+\mathrm{cm}$ depths (Ball et al., 2015; Batey et al., 2015). We consider subsoil compaction an important concern since sugarcane roots have the potential to explore soil layers much deeper than $25 \mathrm{~cm}$.

The VESS scores $(\mathrm{Sq}>3.0)$ found in this study suggest that important management changes are required to mitigate the negative effects of sugarcane cultivation on soil structure and improve its sustainability. Adoption of harvesting without prior burning (e.g., Cerri et al., 2011), minimum tillage and maintaining straw on the soil surface (e.g., Dalchiavon et al., 2013; Segnini et al., 2013) could increase SOC and improve soil structure. Protocols that aim to have machinery enter fields under soil moisture that are less favorable to compaction in conjunction with controlled traffic strategies should also be encouraged to keep soil structure favorable for sustainable sugarcane production.

\subsection{VESS score as an integrative soil structural quality indicator}

Quantitative soil physical properties traditionally used to assess soil structure changes in sugarcane fields have been used for supporting management decisions. Since the VESS method integrates several soil physical properties into a single score, it is convenient that VESS scores are correlated with these quantitative parameters. Fig. 7 shows that VESS Sq scores were significantly correlated with bulk density $(r=0.57-0.75)$, macroporosity $(r=-0.48$ to -0.66$)$, index of soil water storage capacity $(r=0.45-0.71)$, and soil resistance to penetration $(r=0.56-0.72)$, regardless of the inherent properties of the soil (e.g., soil texture, moisture and SOC). VESS scores were positively associated with increases in bulk density, which lead to decreases in macroporosity and increases in water retention (especially in lower water potentials), unbalancing the relationship between air and water in the soil, and finally, increasing the soil impedance to root growth. Overall, the VESS score $(\mathrm{Sq}=3.0)$ used as a threshold to guide management changes in temperate soils was fairly convergent with critical values of: bulk density, $1.2,1.4$ and $1.6 \mathrm{Mg} \mathrm{m}^{-3}$ for clay, medium texture and sandy soils, respectively (Reynolds et al.,

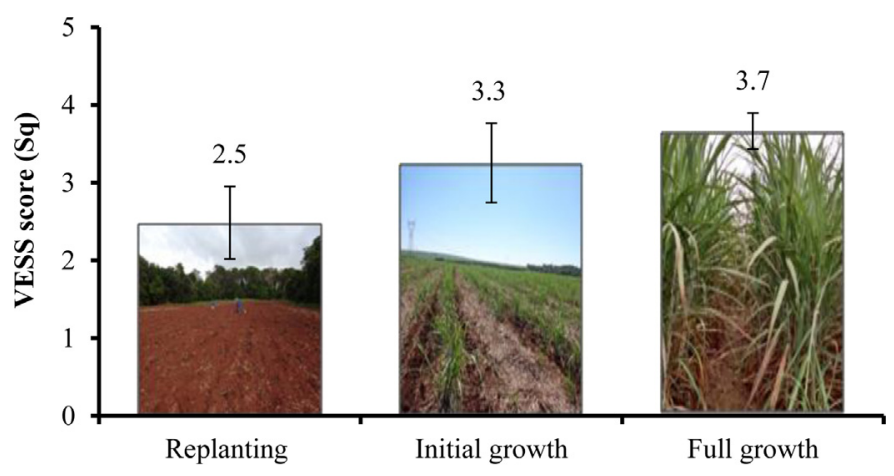

Sugarcane's annual life cycle

Fig. 6. Evolution of VESS scores during the sugarcane's annual life cycle, where, Lat_17S: sugarcane replanting; Lat_23S: initial growth; Lat_21S: full growth. Bars represent the standard deviation of the mean 

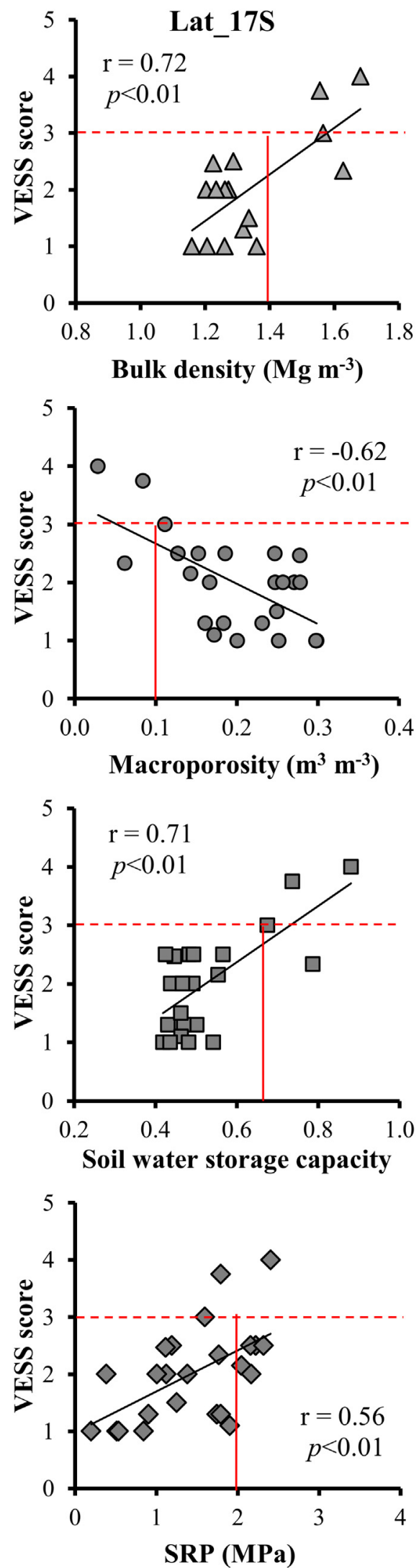
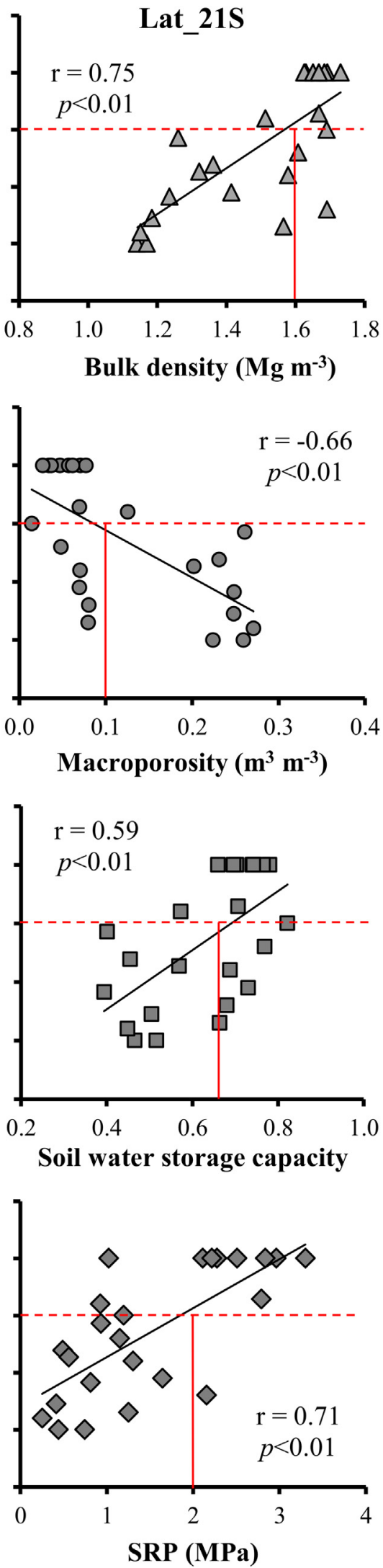
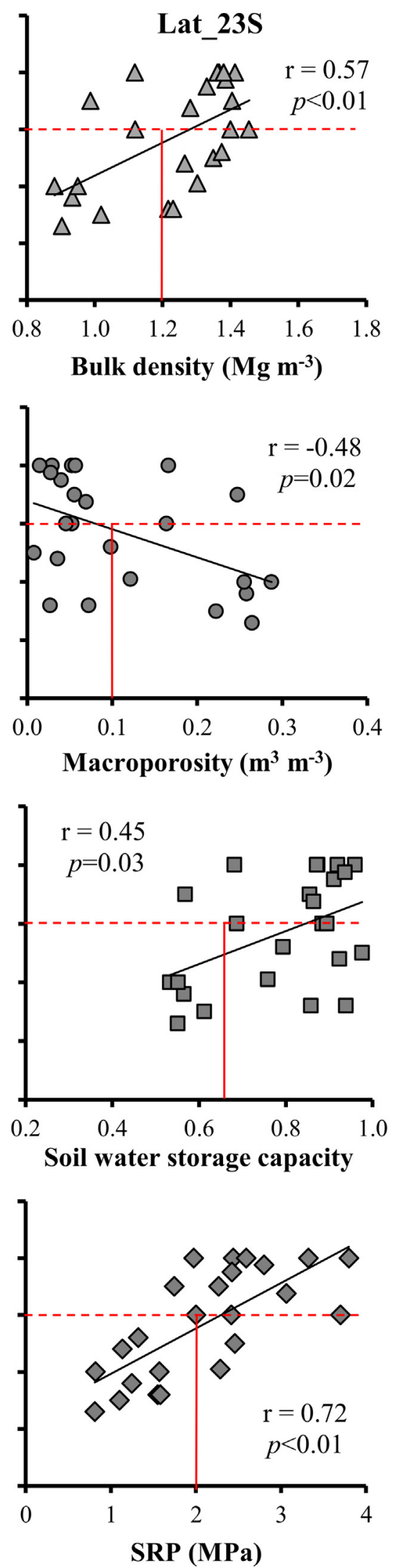

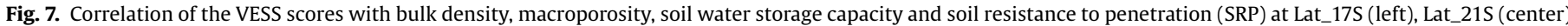

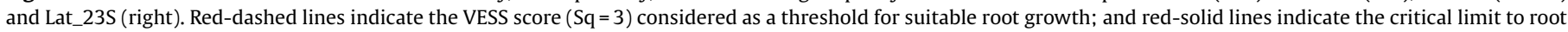

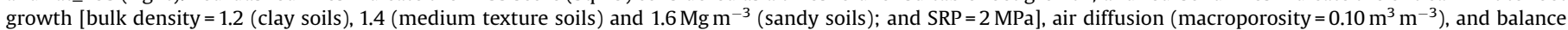

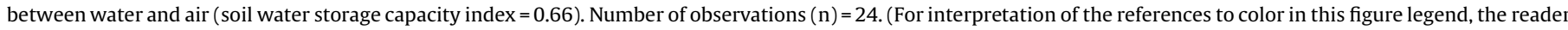
is referred to the web version of this article.) 
2002); macroporosity, $0.1 \mathrm{~m}^{3} \mathrm{~m}^{-3}$ (Xu et al., 1992); soil water storage capacity, 0.66 (Reynolds et al., 2002) and soil resistance to penetration, $2 \mathrm{MPa}$ (Otto et al., 2011). We highlight that the thresholds for VESS (i.e., Sq=3), bulk density, macroporosity and soil water storage capacity were originally developed for temperate soils, and thus, they need to be carefully interpreted when applied for tropical soils. Furthermore, to establish a fixed number that fit well as a critical limit for all soils and management conditions is very difficult or even impossible; however, these thresholds are important to provide general idea about soil changes induced by land use and management practices. Therefore, though VESS score $\mathrm{Sq}=3.0$ and thresholds for other soil physical attributes were not an exact intersection point, in general, the results showed that VESS scores can provide a good first approximation of soil structural quality status, and the VESS score $(\mathrm{Sq}=3.0)$ can be considered as a provisional threshold for guiding farmers and consulters to make better management decisions.

Our results indicated that VESS is a useful and reliable semiquantitative method that integrates physical functions (e.g., water availability, aeration and root growth) related to structural and physical quality of soils. Thus, VESS could be used as an alternative or complementary tool for assessing sugarcane expansion impacts on soil structural quality in Brazilian tropical soils. These results are consistent with Guimarães et al. (2013), who showed that VESS and the Least Limit Water Range (a complex indicator) have converged to identify soil physical conditions highly restrictive to plant growth when $\mathrm{Sq}>3.5$. In addition, quantitative soil physical properties have site-specific responses (Fig. 7), which are highly influenced by inherent soil characteristics, and therefore, become one of the drawbacks of using one of these properties alone as an indicator of soil for structure or soil quality (Newell-Price et al., 2013).

In addition to the ability of VESS to detect soil structure/physical changes, as reported in this study, Mueller et al. (2013) stated that visual methods for soil assessment are useful diagnostic tools for monitoring and controlling overall soil quality over different scales, ranging from within-field to global. Recent studies confirmed that VESS can be used to validate quantitative soil quality indexes that encompassed soil chemical, physical and biological properties (Askari and Holden, 2014, 2015). Therefore, the VESS method should be suggested to sugarcane producers as a practical, easilyperformed and reliable tool for monitoring soil quality degradation. This also helps to reduce cost and time when evaluating soil quality over large sugarcane areas, typical in central-southern Brazil. A future challenge is the automated collection of samples to quantify VESS. This is needed to broaden its use, especially in extensive areas cultivated with sugarcane in Brazil. Finally, development of protocols and training of technicians and consultants on the proper application of VESS are essential steps for its effective use in the assessment and monitoring of soil quality within sugarcane production systems.

\section{Conclusions}

The VESS method was efficiently sensitive for detecting soil structural quality changes, demonstrating its potential for direct on-farm assessment. VESS scores were significantly correlated with quantitative soil physical properties, and the VESS score $(\mathrm{Sq}=3.0)$ is a reliable provisional threshold for guiding management decisions in Brazilian tropical soil under sugarcane cultivation. Land-use conversions from native vegetation to pasture and then to sugarcane led to degradation of soil structural quality. Therefore, sugarcane expansion fields must be monitored to prevent soil physical limitations that can negatively affect growth and yield of sugarcane. We conclude that VESS scores provide an efficient method for identifying soil structural quality degradation induced by LUC, and recommend that VESS evaluations be incorporated into monitoring protocols for evaluating soil quality/health in areas of sugarcane expansion in Brazil.

\section{Acknowledgments}

M.R.C. and A.L.C.F. thank São Paulo Research Foundation(FAPESP) for their scholarships (Processes \# 2013/17581-6; 2014/16612-8 and 2012/22510-8). C.E.P.C, C.C.C and C.A.T thank National Council for Scientific and Technological Development (CNPq) - Brazil for their productivity research grants. C.A.T thanks CNPq - Brazil for his postdoc scholarship (Process \#203376/2014-5).

The U.S. Department of Agriculture (USDA) prohibits discrimination in all its programs and activities. USDA is an equal opportunity provider and employer.

\section{References}

Abdollahi, L., Hansen, E.M., Rickson, R.J., Munkholm, L.J., 2015. Overall assessment of soil quality on humid sandy loams Effects of location, rotation and tillage. Soil Tillage Res. 145, 29-36.

Askari, M.S., Holden, N.M., 2014. Indices for quantitative evaluation of soil quality under grassland management. Geoderma 230-231, 131-142.

Askari, M.S., Holden, N.M., 2015. Quantitative soil quality indexing of temperate arable management systems. Soil Tillage Res. 150, 57-67.

Askari, M.S., Cui, J., Holden, N.M., 2013. The visual evaluation of soil structure under arable management. Soil Tillage Res. 134, 1-10.

Ball, B.C., Batey, T., Munkholm, L.J., 2007. Field assessment of soil structural quality a development of the Peerlkamp test. Soil Use Manage. 23, 329-337.

Ball, B.C., Munkholm, L.J., Batey, T., 2013. Applications of visual soil evaluation. Soil Tillage Res. 127, 1-2.

Ball, B.C., Batey, T., Munkholm, L.J., Guimarães, R., Boizard, H., McKenzie, D., Peigne, J., Tormena, C.A., 2015. The numeric visual evaluation of subsoil structure (SubVESS) under agricultural production. Soil Tillage Res. 148, 85-96.

Ball, B.C., Guimarães, R.M.L., Cloy, J.M., Hargreaves, P., Shepherd, T.G., McKenzie, B. M., 2017. Visual soil evaluation: a summary of some applications and potential developments for agriculture. Soil Tillage Res. 173, 114-124.

Baquero, J.E., Ralisch, R., Medina, C.C., Tavares Filho, J., Guimarães, M.F., 2012. Soil physical properties and sugarcane root growth in a red Oxisol. R. Bras. Ci. Solo $36,63-70$.

Batey, T., Guimarrães, R.M.L., Peigné, J., Boizard, H., 2015. Assessing structural quality for crop performance and for agronomy (VESS, VSA, SOILpak, Profil Cultural, SubVESS). In: Ball, B.C., Munkholm, L.J. (Eds.), Visual Soil Evaluation: Realizing Potential Crop Production with Minimum Environmental Impact. CAB International, pp. 15-30.

Braunack, M.V., McGarry, D.M., 2006. Traffic control and tillage strategies for harvesting and planting of sugarcane (Saccharum officinarum) in Australia. Soil Tillage Res. 86, 86-102.

Bronick, C.L., Lal, R., 2005. Soil structure and management: a review. Geoderma 124, $3-22$.

Castro, A.M.C., Santos, K.H., Miglioranza, E., Gomes, C.J.A., Marchione, M.S., 2013. Avaliação de atributos físicos do solo em diferentes anos de cultivo de cana-deaçúcar. Rev. Agrarian 6, 415-422.

Cerri, C.C., Galdos, M.V., Maia, S.M.F., Bernoux, M., Feigl, B.J., Powlson, D., Cerri, C.E.P., 2011. Effect of sugarcane harvesting systems on soil carbon stocks in Brazil: an examination of existing data. Eur. J. Soil Sci. 62, 23-28.

Cherubin, M.R., Franco, A.L.C., Cerri, C.E.P., Oliveira, D.M.S., Davies, C.A., Cerri, C.C., 2015. Sugarcane expansion in Brazilian tropical soils - effects of land-use change on soil chemical attributes. Agric. Ecosyst. Environ. 211, 173-184.

Cherubin, M.R., Karlen, D.L., Cerri, C.E.P., Franco, A.L.C., Tormena, C.A., Davies, C.A. Cerri, C.C., 2016a. Soil quality indexing strategies for evaluating sugarcane expansion in Brazil. PLoS One 11, e0150860. doi:http://dx.doi.org/10.1371/ journal.pone.0150860.

Cherubin, M.R., Karlen, D.L., Franco, A.L.C., Tormena, C.A., Cerri, C.E.P., Davies, C.A. Cerri, C.C., 2016b. Soil physical quality response to sugarcane expansion in Brazil. Geoderma 267, 156-168.

Companhia Nacional de Abastecimento - Conab. 2016. Acompanhamento da safra brasileira de cana-de-açúcar. v. 2-Safra 2015/16, n. 3, Terceiro Levantamento, Brasília. http://www.conab.gov.br/OlalaCMS/uploads/arquivos/ 15_12_17_09_03_29_boletim_cana_portugues_-_3o_lev_-_15-16.pdf (accessed 04.01.16).

Cui, J., Askari, M.S., Holden, N.M., 2014. Visual evaluation of soil structure under grassland management. Soil Use Manage. 30, 1-9.

Dalchiavon, F.C., Carvalho, M.P., Montanari, R., Andreotti, M., Dal Bem, E.A., 2013. Sugarcane trash management assessed by the interaction of yield with soil properties. Revista Brasileira Ciência Solo 37, 1709-1719. 
Elliott, E.T., 1986. Aggregate structure and carbon nitrogen, and phosphorus in native and cultivated soils. Soil Sci. Soc. Am. J. 50, 627-633.

Foley, J.A., DeFries, R., Asner, G.P., Barford, C., Bonan, G., Carpenter, S.R., Chapin, F.S., Coe, M.T., Daily, G.C., Gibbs, H.K., Helkowski, J.H., Holloway, T., Howard, E.A., Kucharik, C.J., Monfreda, C., Patz, J.A., Prentice, C., Ramankutty, N., Snyder, P.K., 2005. Global consequences of land use. Science 309, 570-574.

Fonte, S.J., Quintero, D.C., Velásquez, E., Lavelle, P., 2012. Interactive effects of plants and earthworms on the physical stabilization of soil organic matter in aggregates. Plant Soil 359, 205-214.

Franco, A.L.C., Cherubin, M.R., Pavinato, P.S., Cerri, C.E.P., Six, J., Davies, C.A., Cerri, C. C., 2015. Soil carbon, nitrogen and phosphorus changes under sugarcane expansion in Brazil. Sci. Total Environ. 515-516, 30-38.

Franco, A.L.C., Bartz, M.L.C., Cherubin, M.R., Baretta, D., Cerri, C.E.P., Feigl, B.J., Wall, D. H., Davies, C.A., Cerri, C.C., 2016. Loss of soil (macro)fauna due to the expansion of Brazilian sugarcane acreage. Sci. Total Environ. 563-564, 160-168.

Giarola, N.F.B., Silva, A.P., Tormena, C.A., Ball, B., Rosa, J.A., 2010. Visual soil structure quality assessment on Oxisols under no-tillage system. Sci. Agric. 67, 479-482.

Giarola, N.F.B., Silva, A.P., Tormena, C.A., Guimarães, L.R.M., Ball, B.C., 2013. On the visual evaluation of soil structure: the Brazilian experience in Oxisols under notillage. Soil Tillage Res. 127, 60-64.

Goldemberg, J., Mello, F.F.C., Cerri, C.E.P., Davies, C.A., Cerri, C.C., 2014. Meeting the global demand for biofuels in 2021 through sustainable land-use change policy. Energy Policy 69, 14-18.

Guimarães, R.M.L., Ball, B.C., Tormena, C.A., 2011. Improvements in the visual evaluation of soil structure. Soil Use Manage. 27, 395-403.

Guimarães, R.M.L., Ball, B.C., Tormena, C.A., Giarola, N.F.B., da Silva, A.P., 2013. Relating visual evaluation of soil structure to other physical properties in soils of contrasting texture and management. Soil Tillage Res. 127, 92-99.

Imhoff, S., Imvinkelried, H., Tormena, C.A., da Silva, A.P., 2009. Calificación visual a campo de la calidad estructural de Argiudoles bajo diferentes sistemas de manejo. Cienc. Suelo (Argentina) 27, 247-253.

Lapola, D.M., Martinelli, L.A., Peres, C.A., Ometto, J.P.H.B., Ferreira, M.E., Nobre, C.A., Aguiar, A.P.D., Bustamante, M.M.C., Cardoso, M.F., Costa, M.H., Joly, C.A., Leite, C. C., Moutinho, P., Sampaio, G., Strassburg, B.B.N., Vieira, I.C.G., 2014. Pervasive transition of the Brazilian land-use system. Nat. Clim. Change 4, 27-35.

Lozano, N., Rolim, M.M., Oliveira, V.S., Tavares, U.E., Pedrosa, E.M.R., 2013. Evaluation of soil compaction by modeling field vehicle traffic with SoilFlex during sugarcane harvest. Soil Tillage Res. 129, 61-68.

Mello, F., Cerri, C.E.P., Davies, C.A., Holbrook, N.M., Paustian, K., Maia, S.M.F., Galdos, M.V., Bernoux, M., Cerri, C.C., 2014. Payback time for soil carbon and sugar-cane ethanol. Nat. Clim. Change 4, 605-609.

Mueller, L., Shepherd, G., Schindler, U., Ball, B.C., Munkholm, L.J., Hennings, V., Smolentseva, E., Rukhovic, O., Lukin, S., Hu, C., 2013. Evaluation of soil structure in the framework of an overall soil quality rating. Soil Tillage Res. 127, 74-84.

Munkholm, L.J., Heck, R.J., Deen, B., 2013. Long-term rotation and tillage effects on soil structure and crop yield. Soil Tillage Res. 127, 85-91.
Newell-Price, J.P., Whittingham, M.J., Chambers, B.J., Peel, S., 2013. Visual soil evaluation in relation to measured soil physical properties in a survey of grassland soil compaction in England and Wales. Soil Tillage Res. 127, 65-73.

Otto, R. Silva, A.P., Franco, H.C.J., Oliveira, E.C.A., Trivelin, P.C.O., 2011. High soil penetration resistance reduces sugarcane root system development. Soil Tillage Res. 117, 201-210.

Pulido Moncada, M., Gabriels, D., Lobo, D., Rey, J.C., Cornelis, W.M., 2014. Visual field assessment of soil structural quality in tropical soils. Soil Tillage Res. 139, 8-18.

Reynolds, W.D., Bowman, B.T., Drury, C.F., Tan, C.S., Lu, X., 2002. Indicators of good soil physical quality: density and storage parameters. Geoderma 110, 131-146.

Santos, R.D., Lemos, R.C., Santos, H.G., Ker, J.C., Anjos, L.H.C., Shimizu, S.H., 2013. Manual de descrição e coleta de solo no campo, 6st ed. Sociedade Brasileira de Ciência do Solo, pp. 102.

Segnini, A., Carvalho, J.L.N., Bolonhezi, D., Milori, D.M.B.P., Silva, W.T.L., Simões, M.L., Cantarella, H., de Maria, I.C., Martin-Neto, L., 2013. Carbon stock and humification index of organic matter affected by sugarcane straw and soil management. Sci. Agric. 70, 321-326.

Shepherd, T.G., 2009. Visual soil assessment, 2nd ed. Field Guide for Pastoral Grazing and Cropping on Flat to Rolling Country, vol. 1. Horizons Regional Council, Palmerston North, pp. 119.

Silva-Olaya, A.M., Cerri, C.E.P., La Scala Jr., N., Dias, C.T.S., Cerri, C.C., 2013. Carbon dioxide emissions under different soil tillage systems in mechanically harvested sugarcane. Environ. Res. Lett. 8, 1-8.

Six, J., Elliott, E.T., Paustian, K., Doran, J.W., 1998. Aggregation and soil organic matter accumulation in cultivated and native grassland soils. Soil Sci. Soc. Am. J. 62, 1367-1377.

Six, J., Bossuyt, H., Degryze, S., Denef, K., 2004. A history of research on the link between (micro) aggregates soil biota, and soil organic matter dynamics. Soil Tillage Res. 79, 7-31.

Soil Survey Staff, 2014. Keys to Soil Taxonomy, 12th ed. USDA - Natural Resources Conservation Service, Washington, DC, pp. 360.

Souza, G.S., Souza, Z.M., Silva, R.B., Barbosa, R.S., Araújo, F.S., 2014. Effects of traffic control on the soil physical quality and the cultivation of sugarcane. R. Bras. Ci. Solo 38, 135-146.

Strassburg, B.B.N., Latawiec, A.E., Barioni, L.G., Nobre, C.A., da Silva, V.P., Valentim, J. F., Vianna, M., Assad, E.D., 2014. When enough should be enough: improving the use of current agricultural lands could meet production demands and spare natural habitats in Brazil. Glob. Environ. Change 28, 84-97.

Tisdall, J.M., Oades, J.M., 1982. Organic matter and water-stable aggregates in soils. J. Soil Sci. 33, 141-163.

Vezzani, F.M., Mielniczuk, J., 2011. Agregação e estoque de carbono em Argissolo submetido a diferentes práticas de manejo agrícola. R. Bras. Ci. Solo 35, 213-223.

Xu, X., Nieber, J.L., Gupta, S.C., 1992. Compaction effect on the gas diffusion coefficient in soils. Soil Sci. Soc. Am. J. 56, 1743-1759. 